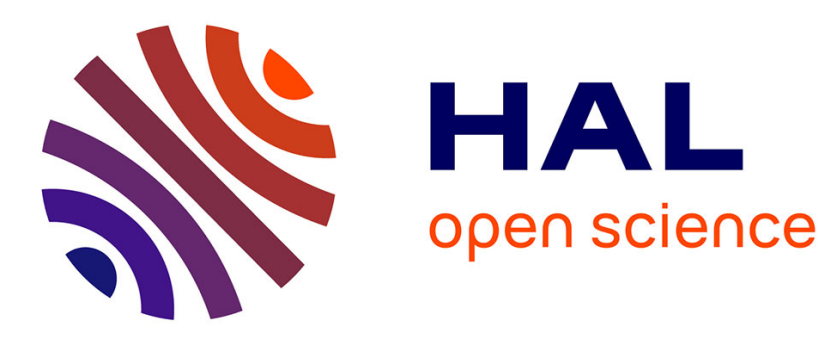

\title{
Mechanical destruction of weeds. A review
}

D. Chicouene

\section{- To cite this version:}

D. Chicouene. Mechanical destruction of weeds. A review. Agronomy for Sustainable Development, 2007, 27 (1), pp.19-27. hal-00886355

\section{HAL Id: hal-00886355 \\ https://hal.science/hal-00886355}

Submitted on 1 Jan 2007

HAL is a multi-disciplinary open access archive for the deposit and dissemination of scientific research documents, whether they are published or not. The documents may come from teaching and research institutions in France or abroad, or from public or private research centers.
L'archive ouverte pluridisciplinaire HAL, est destinée au dépôt et à la diffusion de documents scientifiques de niveau recherche, publiés ou non, émanant des établissements d'enseignement et de recherche français ou étrangers, des laboratoires publics ou privés. 


\title{
Mechanical destruction of weeds. A review
}

\author{
D. Chicouene* \\ Arbiotech, rue de Saint-Brieuc, Z.A. des Bretins, 35590 Saint-Gilles, France
}

(Accepted 7 June 2006)

\begin{abstract}
The various methods of mechanical removal of weeds in relation to their biology are reviewed. Depending on the stage of growth and type of weed, i.e. the depth at which new shoots can be formed and the ability to withstand burial, implements inflict damage on weeds in different ways: cutting, burial or uprooting. The various types of damage are exemplified. The three main methods of destruction are analysed and compared. These are: lethal damage, particularly effective in the case of plantlets; the exhaustion of reserves, effective where either deep or surface organs are targeted; and withering, of special interest where sub-surface parts are involved. Stored reserves can be depleted by either cutting the foliage, burying foliar parts or severely cutting up surface organs of propagation. Withering is accomplished by either cutting the roots, by exposing the roots to the air or by shaking out rootlets. It is shown that the kind of damage is strongly dependent upon the type of organ involved. Advances in our understanding of the way in which mortality occurs are discussed in the light of research.
\end{abstract}

mechanical weed control / plant / morphology / physiology / withering / exhaustion / reserves / plantlets / rhizomes / creeping roots

\section{INTRODUCTION}

The mechanical control of weeds is one of the main traditional methods used in plant production. The expansion of sustainable agriculture in developed countries has brought mechanical destruction methods to the forefront again, as they avoid the use of herbicides. An analysis of cultural methods, as related to the biology of weed plants, forms the basis of research into better weed control. This is an aspect already emphasised by Chancellor (1968). Following intervention in a crop, an understanding of the mechanisms causing weed death or weed survival will be a determining factor in optimising control methods. Depending on the kind of weed involved, the various types of destruction methods should also be reviewed. More often than not, however, where mechanical methods of control of vascular green plants are used, only the final result at the end of the season is taken as a measurement when comparing different protocols (vide Rasmussen, 1992: Harrowing of plantlet weeds; and Palis, 1996: The control of Elymus repens). For many perennial species the mechanisms by which regeneration occurs are discussed in terms of the relationship between the organs and the damage inflicted. This is particularly so in the case of organs which regenerate after intervention (e.g. Irmisch, 1857, who showed that the organogenetic capacity of each organ depends on the plant concerned; Korsmo, 1930; Salisbury, 1962; Hakansson, 1975; Leakey, 1981).

Besides, the mechanisms by which death occurs following the use of mechanical control methods are the subject of only sparsely scattered communications and tend to be limited to a restricted range of perennial weeds:

- The role of the actual level of reserves in Cirsium arvense needed for regeneration to occur was suggested by Prentiss (1889) and added to by Welton et al. (1929) regarding the way in which the level of reserves in the same plant is tied to its annual cycle, by Barr (1940) regarding the use of existing reserves in Convolvulus arvensis and by Timmons (1941) regarding the optimum number of interventions on Convolvulus arvensis aimed at exhausting its reserves.

- In the control of perennials, Hitchcock and Clothier (1898) suggested preventing the build-up of reserves, plus the straightforward pulling up of annuals and biennials. Both these aspects were taken up by Brenchley et al. (1920), but only in the case of plantlets deprived of their capacity to regenerate.

- In their vast review of the subject, Robbins et al. (1942) tackle the subject of the effect of untargeted weed control (i.e. before emergence) on plantlets, pointing out the difference between the importance of the reserves of deeply rooted perennials and that of dehydration for surface rooting species.

- With plants possessing only sub-surface underground parts (particularly Elymus repens and Agrostis sp. pl.), Fail (1956) proposed exhausting reserves by programming at least two successive interventions: the first enabling the production of new shoots, with the second killing them off.

- In addition to annuals and biennials at the plantlet stage which had been totally deprived of their capacity to regenerate, Muzic (1970) made a distinction between preventing the build-up

* Corresponding author: chicouene.daniel@libertysurf.fr 
Table I. Relationship between depth of regenerating organs and effectiveness of implement's mode of action.

\begin{tabular}{|c|c|c|c|c|c|}
\hline \multirow[b]{2}{*}{ Regenerating Organs } & \multicolumn{5}{|c|}{ Type of Implement } \\
\hline & Horizontal Blade & Horizontal Blade & $\begin{array}{c}\text { Discs, Moleboard, } \\
\text { Plough }\end{array}$ & $\begin{array}{c}\text { Tines } \\
\text { (Vibratory Curved) }\end{array}$ & Sub-soiler Tines \\
\hline (non-dormant) & $\begin{array}{l}\text { Deep Cut } \\
\quad(1 \mathrm{dm})\end{array}$ & $\begin{array}{l}\text { Sub-surface Cut } \\
\quad(2 \mathrm{~cm} \text { deep })\end{array}$ & $\begin{array}{l}\text { Green Parts Buried } \\
\text { (Overturned or not) }\end{array}$ & $\begin{array}{l}\text { Uprooting (to } 1 \mathrm{dm} \text { ) } \\
\text { Green parts and } \\
\text { roots left exposed }\end{array}$ & $\begin{array}{c}\text { Rootlets Shaken Leafy } \\
\text { parts } \\
\text { left untouched }\end{array}$ \\
\hline $\begin{array}{l}\text { Plantlet } \\
\text { (without reserves) }\end{array}$ & $\begin{array}{c}(0 \text { to }+) \\
\mathrm{W}\end{array}$ & $\begin{array}{c}+(+)^{*} \\
\mathrm{~W}\end{array}$ & $\stackrel{+}{\mathrm{E}(\& \mathrm{~W})}$ & $\begin{array}{c}+ \\
\mathrm{W}\end{array}$ & $\begin{array}{l}(+) \\
W\end{array}$ \\
\hline $\begin{array}{l}\text { Surface Organs } \\
\text { (stolons or rosettes) }\end{array}$ & $\begin{array}{l}0 \text { to }(+) \\
\text { W }\end{array}$ & $\begin{array}{l}+ \\
\mathrm{W}\end{array}$ & $\stackrel{+}{+}$ & $\begin{array}{c}+ \\
\mathrm{W}\end{array}$ & $\begin{array}{l}(+) \\
\mathrm{W}\end{array}$ \\
\hline $\begin{array}{l}\text { Sub-surface Organs } \\
\text { (in first } 1 \mathrm{dm} \text { ) }\end{array}$ & $\begin{array}{l}(0) \\
W\end{array}$ & $\begin{array}{c}(+) \\
\mathrm{W} \& \mathrm{E}\end{array}$ & $\begin{array}{c}+(+) \\
\mathrm{E}(\& \mathrm{~W})\end{array}$ & $\begin{array}{c}+ \\
\mathrm{W}\end{array}$ & $\begin{array}{l}(+) \\
W\end{array}$ \\
\hline $\begin{array}{l}\text { Surface and Underground } \\
\text { Organs }\end{array}$ & $\begin{array}{l}(+ \text { to } 0) \\
\mathrm{W} \& \mathrm{E}\end{array}$ & $\begin{array}{l}(+ \text { to } 0) \\
\mathrm{W} \& \mathrm{E}\end{array}$ & $\begin{array}{c}+(+) \\
\mathrm{E}(\& \mathrm{~W})\end{array}$ & $\begin{array}{l}+ \text { to } 0 \\
W \& E\end{array}$ & $\begin{array}{c}+(+) \\
W(\& E)\end{array}$ \\
\hline Underground Organs & $\begin{array}{l}+ \\
\mathrm{E}\end{array}$ & $\begin{array}{c}(+) \\
\mathrm{E}\end{array}$ & $\begin{array}{l}+ \text { to }(+) \\
\mathrm{E}(\& \mathrm{~W})\end{array}$ & $\begin{array}{l}(+) \text { to }- \\
\text { E }\end{array}$ & $\begin{array}{c}(+) \\
\mathrm{W}(\& \mathrm{E})\end{array}$ \\
\hline Deeply Buried Organs & $\begin{array}{l}+ \\
\mathrm{E}\end{array}$ & $\begin{array}{c}(+) \\
E\end{array}$ & $\begin{array}{c}+ \text { to }(+) \\
\text { E }\end{array}$ & $\begin{array}{l}(+) \text { to }- \\
\text { E }\end{array}$ & $\begin{array}{c}(+) \\
\mathrm{W}(\stackrel{E}{ })\end{array}$ \\
\hline
\end{tabular}

* Dependent on depth of emergence.

$+=$ Effective; 0 = Ineffective; $-=$ Negative effect \& to be avoided; ()$=$ Marginal; $W=$ Withering; $E=$ Exhaustion of reserves.

and using up of reserves - these being influenced by meteorological conditions.

- With damaged perennial grasses (Elymus repens, Holcus mollis and Agrostis gigantea) Hakansson and Wallgren (1975) observed drying up and exhaustion of reserves in rhizomes only - particularly those near the surface.

- For some plantlets arising from seed, Jones et al. (1996) showed that they could be controlled by simply cutting back to soil level or by burial.

The three main methods of control are exhaustion of reserves, provoking withering and depriving the plant of any capacity to regenerate. In addition, several authors suggest exposure to cold (e.g. Muencher, 1955). With such varied points of view an overall historical review is needed.

The factors influencing the ploughing up of stubble in an area in western France possessing a hyperoceanic temperate climate were analysed by Chicouene (1999). Underground organs are often sectioned horizontally and, depending on the particular weed involved and the depth in the soil, either both upper and lower parts, or just one or neither is capable of regeneration. Thus, the reasoning and methods involved in ploughing up stubble, etc., aimed principally at causing withering or exhaustion of reserves, differ according to the type of weed. The weed list for the area studied showed that each species was characterised by: a calendar governing the capacity for regeneration (Chicouene, 1996), a vegetative period and, for those with underground propagation, the way in which the organs of propagation and regeneration were arranged. Plants dormant in winter, theoretically sensitive to cold, tended to have the deepest organs, often below the ploughed layer. Such comparative lists are, however, available for only a very few areas.

Reviewing historically the diverse mechanisms leading to the weed's death is useful when trying to judge whether trial protocols have, a priori, been optimised and whether the strategy used in mechanical control is best adapted to the particular weed involved. Such mechanical control covers stubble ploughing, tillage, harrowing, furrowing, ground preparation for sowing, etc. This is a conceptual framework that deals with factors influencing the plants' sensitivity to being damaged, the damage types induced by various implements, and discovery in a systematic way. Justifying the effort involved in using a particular method of mechanical control for a chosen weed assumes choosing the right implement, adjusting it properly, and the criteria for deciding on the correct timing for intervention. The types of damage inflicted on each plant type should be analysed when working out a strategy. This implies that weeds should be classified by different forms in which they occur and the various ways in which implements inflict damage on them.

\section{WAYS IN WHICH IMPLEMENTS WORK IN RELATION TO THE CHARACTERISTICS OF REGENERATING ORGANS}

Before studying the way different implements act against weeds it is worth analysing each of the above two aspects separately in order to show how implements vary in their effect.

\subsection{The weed plants and the organs responsible for regeneration}

A description of the factors governing what happens to the weed plant centres on the position of the underground organs and the plant's state of growth. According to the type of organ involved in regeneration (particularly those buried deep) weed plants are classified according to Tables I, II. Such plants are either stationary species or those which propagate vegetatively. 
Table II. Relationship between regenerating organs and method of destruction and effectiveness of damage inflicted on weed organ.

\begin{tabular}{|c|c|c|c|c|c|c|}
\hline \multirow[b]{2}{*}{$\begin{array}{l}\text { Regenerating } \\
\text { Organs }\end{array}$} & \multirow[b]{2}{*}{$\begin{array}{c}\text { Rootlets shaken } \\
\text { out }\end{array}$} & \multirow{2}{*}{$\begin{array}{c}\text { Withering } \\
\begin{array}{c}\text { Underground organs } \\
\text { exposed to air }\end{array}\end{array}$} & \multirow[b]{2}{*}{$\begin{array}{c}\text { Roots cut } \\
\text { (Near surface) }\end{array}$} & \multirow[b]{2}{*}{ Leaves cut } & \multicolumn{2}{|c|}{ Exhaustion of Reserves } \\
\hline & & & & & $\begin{array}{c}\text { Regenerating } \\
\text { organs also cut up }\end{array}$ & $\begin{array}{l}\text { Green parts } \\
\text { buried }\end{array}$ \\
\hline $\begin{array}{l}\text { Organs on } \\
\text { Soil Surface }\end{array}$ & $+(+)$ & $+(+)$ & + & $(0)^{1}$ & $(+)$ & + \\
\hline Sub-Surface & $+(+)$ & + & $(+)^{2}$ & $(+)^{3}$ & + & $(+)$ \\
\hline $\begin{array}{l}\text { Sub-surface and } \\
\text { Underground }\end{array}$ & $\begin{array}{l}\text { If taproots: + } \\
\text { If not: }(+)\end{array}$ & 0 & $(+)$ & $(+)$ & $(+)$ & $(+)$ \\
\hline Underground & $+(+)$ & $0^{4}$ & - & + & 0 & $(+)^{5}$ \\
\hline Deep down & 0 & - & - & + & 0 & $(+)^{5}$ \\
\hline Type of Implement & $\begin{array}{c}\text { Long Prongs Ripper } \\
\text { Tines }\end{array}$ & $\begin{array}{c}\text { Vibratory } \\
\text { Curved Tines }\end{array}$ & $\begin{array}{l}\text { Horizontal } \\
\text { sectioning }\end{array}$ & $\begin{array}{l}\text { Horizontal } \\
\text { sectioning }\end{array}$ & $\begin{array}{c}\text { Horizontal Rotary } \\
\text { Blades }\end{array}$ & $\begin{array}{c}\text { Discs } \\
\text { Furrow Plough }\end{array}$ \\
\hline
\end{tabular}

$+=$ Effectiv; 0 = Difficult; $-=$ Not possible; $($ ) = Marginal.

1 Mowing partly eliminates leafy parts.

${ }_{3}^{2}$ Cutting roots which arise at different depths can be difficult - one should pass just below the deepest plagiotropic organs.

${ }^{3}$ Necessitates being able to pass at approximately $1 \mathrm{~cm}$ depth.

${ }_{5}^{4}$ An intervention, involving a sorting out, will be needed.

${ }^{5}$ Because of the usually low depth of burial, results will not tend to be significant.

\subsubsection{Surface regenerating organs}

Organs situated on the soil surface which give rise to new shoots correspond to plants for which all stems are aerial, and are the only parts capable of regeneration. The plants involved include those producing stolons, stationary species, fully grown perennials and annuals (there was no evidence of underground propagation in the latter in the flora studied) and those at the plantlet stage.

\subsubsection{Underground regenerating organs}

The underground organs capable of forming new shoots (i.e. taproots, rhizomes and creeping root systems) form at depths which vary from species to species (Hakansson, 1982; Chicouene, 1992, 1999). They can be classified as follows:

a. Superficial organs situated in the first few centimetres of the soil and so affected by topsoil work such as Hypericum perforatum. These belong to rhizomatous plants and some stationary species, plus those with creeping root systems.

b. Those extending into the remaining workable layer and unaffected by topsoil work such as Mentha arvensis.

c. Those extending below the ploughable layer (in plants propagating vegetatively the orthotropic part of the underground stem is quite long), such organs being, at best, hardly affected by sub-soiling, such as Equisetum telmateia.

d. Hybrid types of organ: these being a combination of "surface" organs and those descending to varying soil depths or simply being a combination restricted to the latter. A combination of type "a" and "b" would, for example, correspond to the whole of the workable soil layer. A plant such as Taraxacum officinale with a taproot possessing a pronounced capacity for regenerating (Mann and Cavers, 1979) falls into a combination of "a"+"b"+"c".

\subsubsection{Dormant regenerating organs}

Dormant organs and seeds are capable of sprouting and germinating provided that dormancy is not pronounced, surface moisture is sufficient, and burial is not deep as far as reserves are concerned. For example, fine seeds will not germinate if covered by more than $1 \mathrm{~cm}$ of soil, whilst large dormant organs sprout even if buried at the bottom of the plough furrow.

\subsubsection{Special case of plantlets}

Weed plantlets are fragile prior to and just after emergence; plant reserves, having been used up, are usually incapable of regenerating. Plant architecture closely resembles that of surface organs (i.e. less than $2 \mathrm{~cm}$ from the soil surface, above or below).

\subsection{Ways in which implements work and type of damage inflicted}

The types of damage inflicted on weed plants (including those Chicouene, 1999, described for stubble ploughing) can be classified as follows:

- Horizontal sectioning of generally deeply buried underground organs, e.g. by using a stubble-harrow with horizontal blades resulting in an upper and lower plant part;

- Straightforward burial (e.g. when ploughing furrows) results in green parts being covered with soil;

- Burial resulting from overturning (e.g. mould-board or disc plough) which involves a degree of uprooting due to horizontal sectioning;

- Vertical sectioning cuts up those organs which are generally growing horizontally (particularly those laying perpendicular to the path of implements with moving parts); 
- The crushing and shredding of organs caused by disturbance (particularly that caused by tine harrows);

Movement of underground organs to the surface, or towards it. Implements such as a flex-tine cultivator result in a certain degree of separation of the weeds from their soil (i.e. uprooting).

Certain implements cause more than one type of damage, for example:

- Cultivators and vibro-cultivators cause the above last three types;

- Ploughs are noted for sectioning deep down and burial due to overturning;

- Rotary cultivators result mainly in horizontal superficial sectioning plus partial burial and overturning;

- After ploughing, rotary cultivators and ordinary cultivators reduce the amount of burial caused by the plough by, for example, bringing stolons closer to the surface;

- Cover crop implements section organs in various directions (mainly horizontal, but also vertical) plus a degree of partial burying;

- Potato harvesters result in a sorting out, along with significant horizontal sectioning.

The way in which each implement works can depend on soil texture and structure. In loose ground for example, sorting out is better whilst vertical sectioning is poorer.

\subsection{Impact on the plant}

The way in which an implement damages the weed plant is determined by the regenerating organs' own particular architecture (Tab. I). The depth at which the regenerating organs are found, combined with the particular way in which the implement works, results in one of three different situations:

- Organs formed on the surface can either be deprived of their roots (cut near the surface), have their roots exposed to the air or simply be buried.

- Organs situated in worked soil layers may suffer any one of the types of damage mentioned above (i.e. uprooted, buried, etc.). However, deep roots and stem parts can pass between machine prongs and are largely unaffected by vertical sectioning. - Those regenerating organs situated below the worked soil layer can finish up deprived of green parts irrespective of the depth various implements section them. Nonetheless, vertical sectioning has little or no effect and, as in the previous situation, the end result is a proliferation of this particular type of weed.

Such results can sometimes be dependent on weed plant phenology. For example, Magnusson et al. (1987) considered the production of new shoots in Cirsium arvense from stem sections to be no more than an accessory.

After intervention, seeds may finish up being covered, and cracked ground can also be responsible for seeds being buried. Depending upon size, such burial has differing results: germination of larger seeds being favoured, with that of fine seeds being less likely. However, ploughing may bring each seed to the surface where it may still germinate.

\section{DESTRUCTION AND ORGANS LIKELY TO REGENERATE}

The degree to which weed plants withstand exposure to mechanical destruction varies according to their reserves. The tendency for resistance to being damaged or for survival appears to be as follows:

1. The survival rate for plantlets is less than that for fully grown plants; a phenomenon already remarked upon by Klingman (1961), Arny (1927) and Anon. (1968).

2. The survival rate for fully grown annuals is less than that for fully grown perennials (as Hitchcock and Clothier, 1898, and Anon., 1968, have already pointed out).

Fully grown perennials are therefore generally the most difficult of all to combat, whilst plantlets and annual weeds are easier to eradicate. However, exceptions probably occur in the latter case. The actual mechanisms by which death occurs in annual and perennial weeds are not usually mentioned in the literature, even though exhaustion of reserves and withering are often cited as the cause in fully grown perennials.

In practice, one of two situations is possible after inflicting damage: either some plants (or plant fragments) retain the capacity to regenerate if left lying on the surface with sufficient moisture; or others never regenerate, even when conditions are favourable.

What follows below is an analysis of the various types of destruction in which plant organs retain the capacity for regeneration. This is followed up by a review of the different types of damage that are fatal. An intermediate type of damage involving the slowing down and restriction of plant development, due to amputation of plant organs (e.g. an annual's roots), is not dealt with.

\subsection{Eradication of Organs Capable of Regenerating}

Included under this heading are those plants, or at least their detached parts, remaining capable of regeneration under favourable conditions. Actual regeneration depends on numerous parameters which are compared below and considered from the standpoint of the two main limiting factors, i.e. water loss and exhaustion of reserves (Tabs. I-III).

\subsubsection{Principles}

\section{Withering:}

Numerous authors write about causing withering in weeds; for example, Robbins et al. (1942) for weeds with surface rooting systems, F.A.O. (1958) where the action of cultivators on Elymus repens rhizomes is cited, Evans (1962) in the case of ground disturbance of put-aside land aimed at limiting perennials, Anon. (1968) judged worthwhile for surface roots in soil with a poor water-retention capacity, Hakansson (1982) writes of the value, where warm climates operate, of leaving the rhizomes and roots to dry out, F.A.O. (1988) suggests drying out by exposure to the air, Jones et al. (1996) who write about annual weeds and Zimdahl (1993).

Although withering is valid for organs found at various depths, it is probably more effective for those near or actually 
Table III. Importance of factors involved in exhaustion of reserves and withering.

\begin{tabular}{|c|c|c|}
\hline Factor & Exhaustion of Reserves & Withering \\
\hline Meteorology & No apparent effect & $\begin{array}{c}\text { Determinant } \\
\text { (Dry spell needed afterwards) }\end{array}$ \\
\hline Organ Reserves & Determinant & Theoretically no, or little, effect \\
\hline Physical parameters of regenerating organs & $\begin{array}{c}\text { Length } \times \text { Diameter } \\
\times \text { Amount of reserves } \\
(\times \text { Depth of soil to be traversed })\end{array}$ & $\begin{array}{c}\text { Impermeability } \\
(\times \text { Diameter }) \\
(\times \text { Length of remaining roots }) \\
(\times \text { Number of leaves left })\end{array}$ \\
\hline $\begin{array}{l}\text { If fragile (e.g. plantlet): } \\
\text { "Duration" \& depth to which worked }\end{array}$ & $\begin{array}{l}\text { Single intervention at surface level } \\
\text { (with death occurring after several days) }\end{array}$ & $\begin{array}{l}\text { A single intervention at surface level } \\
\text { followed by a day without rain }\end{array}$ \\
\hline $\begin{array}{l}\text { If resistant (e.g. adult perennial): } \\
\text { Type of organ involved }\end{array}$ & Large organs & $\begin{array}{l}\text { Impermeable organs (epidermis, suber) } \\
\text { (Large diameter also slows drying out) }\end{array}$ \\
\hline- & - As deep as possible & \\
\hline Depth of soil to be worked & $\begin{array}{l}\text { (if upper part regenerates) } \\
\text { - Just above regenerating organs } \\
\text { (where lower fragment sprouts) }\end{array}$ & $\begin{array}{l}\text { Depends on depth of sprouting organs } \\
\text { (Pass just below them) }\end{array}$ \\
\hline- & - & - \\
\hline $\begin{array}{l}\text { Duration \& No. of interventions } \\
\text { (Depends on aim } \\
\text { i.e. slowing down of spread/eradication) }\end{array}$ & $\begin{array}{l}\text { For complete eradication: } \\
\text { at least 3-4 times at intervals of } 2-3 \text { weeks } \\
\text { (slow action) }\end{array}$ & $\begin{array}{l}\text { Possibly one month of sunny dry weather } \\
\text { (One period sufficient if good climate) }\end{array}$ \\
\hline $\begin{array}{l}\text { Type of plants destroyed } \\
\text { (Regenerating organs) }\end{array}$ & $\begin{array}{c}\text { All types } \\
\text { (but difficult to obtain } \\
\text { for organs close to surface) }\end{array}$ & $\begin{array}{l}\text { Organs on surface, } \\
\text { Organs near to surface, } \\
\text { (indeed Deep taproots). }\end{array}$ \\
\hline $\begin{array}{l}\text { Implements } \\
\& \\
\text { Interventions }\end{array}$ & $\begin{array}{c}\text { Plough, Furrowing } \\
\text { Discs, Cutting, } \\
\text { Finger harrows used on cereal crops, Hoes, } \\
\text { Stubble cultivators, Potato harvesters, Flexityned } \\
\text { hoes }\end{array}$ & \\
\hline $\begin{array}{l}\text { Implements } \\
\& \\
\text { Interventions }\end{array}$ & $\begin{array}{c}\text { Plough, Furrowing } \\
\text { Discs, Cutting, } \\
\text { Finger harrows used on cereal crops, Hoes, } \\
\text { Stubble cultivators, Potato harvesters, Flexityned } \\
\text { hoes }\end{array}$ & $\begin{array}{l}\text { Finger harrows used on cereal crops, Hoes, Stubble } \\
\text { cultivators, Potato harvesters, Flexityned hoes }\end{array}$ \\
\hline
\end{tabular}

on the surface. In practice, it consists of separating the plant from its roots in one of three ways (Tab. II):

- Amputating the roots by cutting them near their point of insertion (in dry weather stems dessicate rapidly).

- Exposing the roots to the air (for example, where surface rooting weeds are involved, after the passage of a potato harvester).

- Shaking out the rootlets on regenerating organs (main roots and rootstock) by passing deep down below them; for example, in the control of Rumex crispus with a sub-soiler. It should be noted that where foliage remains exposed to the air and attached to regenerating parts, transpiration will contribute to the loss of water in underground organs.

\section{Exhausting reserves:}

Exhausting the stored reserves of either the whole plant or detached parts is dealt with in a number of reviews and treatises on weed science, for example: Buckman (1855), Hitchcock and Clothier (1898), Brenchley (1920), Muencher (1955), F.A.O. (1958), Klingman (1961), Evans (1962), Anon. (1968), Muzic
(1970), Fryer and Evans (1970), F.A.O. (1988), Hakansson (1982) and Zimdahl (1993). Certain authors advise acting before the accumulation of reserves, others advise exhausting stored reserves and yet others both (Vide Muzic, 1970). Where storage organs last for more than one season and function more than once, both methods are often used in tandem.

Stored reserves can be exhausted in one of three ways:

- Where weeds possess only very deep regenerating organs they are finally worn down after repeatedly destroying green parts. Such a solution is advocated by Robbins et al. (1942), Muencher (1955), F.A.O. (1958) and Anon. (1968), and in particular, has been tried out by Welton et al. on Cirsium arvense (1929), by Barr on Convolvulus arvensis (1940) and by Pavlychenko, especially on Cirsium arvense and Sonchus arvensis (1940). Cutting most of the underground orthotropic stem, plus green parts, should help the depletion process when such parts have a poor capacity for regenerating;

- By severely cutting up surface storage organs and then allowing them to sprout, and then killing them off by various methods, as suggested by Fail (1956); 
- By burying the green parts to force the plant to produce new growth to reach the surface. This may be repeated if burial is not deep enough to exhaust the plant in a single pass, which is the case with certain large rosettes which produce new growth after being well ploughed up.

In theory, reserve depletion is independent of meteorological conditions. However, Muzic (1970) suggested that conditions favouring growth accelerate the process.

Plant organs are considered depleted when, following intervention, they no longer produce new aerial shoots at a time when the species would normally be growing (assuming growth to be seasonal). However, the actual mortality of these organs remains to be verified.

If a plant has both regenerating surface and underground organs, a campaign against those on the surface helps to exhaust deeper organs at the same time, provided that:

- All orthotropic stems originating deep down are decapitated, and (in the case of rhizomatous weeds) the upper part extracted;

- All green parts are ploughed under.

\subsubsection{Tolerance}

The plant variables affecting the degree to which it withstands mechanical intervention differ according to the particular physiological processes leading to its death.

\section{- Withering}

For death due to withering, which may take anything from less than a day to a month or longer, the rate of drying is dependent on the impermeability and thickness of the organ, plus the degree to which leaves persist. If it should rain before complete drying out and the plant re-develops roots, the operation should be repeated in order to avoid simply slowing down development (i.e. causing no more than a temporary perturbation). Regenerating organs that are deeply buried cannot be properly brought to the surface and are, therefore, poorly accessible to this kind of destruction - except perhaps sub-soiling, which may affect taprooted weeds. Grummer (1963) shows that short pieces were more susceptible than longer fragments of rhizomes of Elymus repens.

\section{- Exhausting reserves}

Concerning eradication of perennials, optimising the number and the length of time between interventions is dealt with by various authors, in particular by: Timmons on Convolvulus arvensis (1941), Seely on Cirsium arvense (1952) and Derscheid et al. (1961) on Cirsium arvense and Sonchus arvensis. They reveal that a delay of more than 10 days will suffice. The precaution of preventing leaf growth, mentioned by Hitchcock and Clothier (1898) and Pavlychenko et al. (1940), does not seem to be of use. Timmons (1941), in fact, showed that the amount of reserves held in the roots of Convolvulus arvensis continued to decrease up to 15 days after emergence, whilst Muzic (1970) thought that young aerial shoots used up more reserves than they produced.

To obtain complete exhaustion of reserves in perennials one will, generally, need to intervene several times at intervals of a few weeks (i.e. during the growth season). For a weed prop- agating vegetatively, the actual number of interventions will vary according to whether the aim is to slow down its progression, to stabilise its extent at its current limits, to obtain a decrease in its abundance or to eliminate vegetative organs. It is possible that, with certain species, a single intervention each year will not be enough to obtain a decrease in population size. Moreover, Hodgson (1972) showed that tolerance to intensive perturbation of Cirsium arvense populations varied according to the ecotype involved. As a consequence, a control programme should not be based on information from a single population.

Numerous authors have demonstrated, with weeds which have rhizomes or creeping roots, the relationship between the size and the depth of buried organ fragments, and their capacity to regenerate. Different studies have been undertaken for species normally possessing (according to Chicouene, 1992) underground propagation at different depths. For example, Prentiss (1889) investigated the length and diameter of creeping roots of Cirsium arvense, Hakansson (1967) different stages of development of Elymus repens rhizomes and (1969) the creeping roots of Sonchus arvensis, Hakansson and Wallgren (1975) the rhizomes of Elymus repens, Holcus mollis and Agrostis gigantea, and Bourdot (1984) the probable perennial rhizomes of a wintergreen dicotyledon: Achillea millefolium. All of these studies showed that the more reserves an organ contained, the more it was capable of regenerating; i.e. the more interventions it was able to withstand. It may therefore be worthwhile looking at using a sub-soiler to cut up deep organs in order to reduce the number of interventions needed to exhaust reserves, so reducing the overall time for this to occur. The commonly used types of implement are ineffective at cutting up underground organs such as rhizomes of Equisetum telmateia.

With an intact root system, the greater the depth of soil the plant has to penetrate to reach the surface the more, in theory, it uses up its reserves. Fewer interventions will, therefore, be needed. Such circumstances can be created by either burying green parts and regenerating organs deep down, or by cutting off a large section of the underground orthotropic stem. Nevertheless, with Convolvulus arvensis, Barr (1940) was unable to show such an effect in a trial which compared results from one depth and double that depth. In a trial run by Timmons (1941), and which covered depths varying by three times, depth had little effect on the number of interventions needed. The performance of different morphological types would therefore be worth investigating during their period of underground development. Certain plants produce only a single finely drawn out leaf, whilst others produce a stem with burrowing leaves straight away (Chicouene, 1991).

If organs for vegetative propagation are only distributed throughout the worked soil layer then any shoots of those tips exposed to the air will have no soil to traverse to find daylight. One would therefore expect a weak effect on the wearing down of reserves caused by a single intervention - which is probably why Pavlychenko et al. (1940) failed in their efforts to control Elymus repens in rainy years.

Certain authors have based themselves on the level of reserves (e.g. Welton et al., 1929, writing about Cirsium arvense; Arny, 1932, writing about five different species, one 
of which was the winter-green rhizomatous Elymus repens and Barr, 1940, writing about Convolvulus arvensis), and they have all sought to intervene during flowering when reserves were at their lowest. With Elymus repens, however, there is little variation in the level of reserves. Observations were primarily done on summer dicotyledons possessing creeping roots. Klingman (1961) probably falls into such a case when he based his programme for exhaustion of reserves on theory. The difficulty in such trials is knowing the level of reserves for organ death to occur. Another gap in our present knowledge is that we do not know whether it is better to wait until the plant reserves reach their lowest annual level naturally, or to intervene as soon as possible. The latter could possibly lead to lower levels than those attained naturally despite the plant's normal cycle being upset.

The reasoning regarding the level of reserves needs to take into account their total overall amount - in which the actual size of the plant organs plays a role. Thus, where tubercles are annual, e.g. particularly with rhizomatous summer dicotyledons, intervention can be planned for when they are absent. This presupposes a knowledge of the phenology of the renewal of organs and the formation of tubers, as well as the degree to which the crop itself prevents weed development. By anticipating the accumulation of reserves, and the consequent formation of organs for vegetative propagation, it is possible to limit the spread of weed patches.

\subsubsection{Combinations of different methods of eradication}

Exhausting reserves and causing withering are tactics that can be used simultaneously or separately. A combination of both methods - possible during a dry spell - involves simultaneously subjecting the same plant organ to both such tactics. Successive work during a dry spell can correspond to such a situation (Hakansson and Wallgren, 1975 and Palis, 1996 writing about Elymus repens) for organs found throughout the worked soil layer in which the work mixes and fragments them and amputates the roots of their rhizomes.

In the case of plants sectioned horizontally, where both parts can regenerate, elimination is obtained by allowing the upper part to wither, or withering in combination with exhaustion of reserves, and exhausting the reserves of the lower half (Tab. II). Should rain occur after such an operation then only the exhaustion of reserves will have some effect (weak). If dryness is not pronounced it may be possible to calculate the depth at which sectioning should occur to ensure that the upper part withers. However, the shallow depth at which sectioning must be done will dictate a greater number of interventions if the lower part's reserves are to be exhausted.

Logically, withering does not cut off food reserves; nor does exhaustion reduce water reserves. Also, where a succession of interventions is involved, particularly those aimed at surface organs, changing the method would probably translate to going back to square one. With superficial plagiotropic organs, starting by allowing plant fragments to sprout (which exhausts their reserves) under moist conditions, and then allowing the new sprouts to dry out after a second intervention is, theoretically, the only exception to this rule. Experimental evidence concerning all such aspects is indispensable in planning a practical strategy for the species, conditions and development stages.
This is also needed for estimating the effectiveness and sensitivity to failure.

\subsubsection{Dormant vegetative organs}

All weed species do not grow at the same time, nor do all tubercles of a species with a seasonal growth cycle enter this cycle simultaneously. Consequently, the weed flora of a given field will not be controlled simultaneously. Exhaustion of food reserves will obviously be ineffective if plant organs are not growing. For at least some weeds appearing in winter, causing them to wither in summer will also produce equally poor results (those species with dormant tubercles above the surface show high resistance in summer), It sometimes happens that disturbance sparks off unseasonal growth (Chicouene, 1991) and depending on the size of plant fragments, sprouting may be possible even after burial.

Exposing underground organs (normally those of weeds appearing in the summer) to the cold (as suggested by Muenscher, 1955 and King, 1966) or to winter pests can cause them to die. However, this may not be enough to make the practice a viable one - particularly because many summer weeds possess organs below the worked soil layer (Chicouene, 1992).

\subsection{Lethal damage}

\subsubsection{Principles}

In contrast to the previous group, no part manages to regenerate a new plant, even when situated on the surface or even when not exposed to water loss. The literature provides little information on the subject. In general, what is called lethal damage here is more or less implicitly assessed as such, since the weed's disappearance is considered to be simply due to intervention. According to the type of weed control used, the approach to the subject falls into one of two categories:

- The destruction of plantlets, particularly those on prepared ground left lying before sowing and those hit by untargeted harrowing, where no type in particular is concerned (certain authors put the accent on plantlets of perennials) is cited by Brenchley (1920), Arny (1927), Drottij (1929), Robbins et al. (1942), F.A.O. (1958), Klingman (1951), Evans (1962), Anon. (1968), Muzic (1970), F.A.O. (1988), Jones et al. (1995) and Rasmussen (1996). Ilnicki and Fertig (1962) and Boyd and Murray (1982) show seedlings clipped off the perennial Solanum (Solanum carolinense or S. eleagnifolium) died until the age of 10 days.

- The destruction of fully grown, or nearly fully grown plants during hoeing, harrowing and other mechanised work is broached by the following: Hitchcock and Clothier (1898); Robbins et al. (1942) who stipulate that top growth should be destroyed; Evans (1962) who limits himself to entertaining the idea of upsetting growth; King (1966); Anon. (1968); Muzic (1970) who puts the accent on removing the rooting system; F.A.O. (1988) and Jones et al. (1966) who compare different types of damage in annuals.

Closely cropped cuts should also be mentioned (i.e. cuts at the level of the aerial part of the hypocotyls - when they exist - which probably correspond to certain trial procedures used by Jones et al., 1995) as well as the chopping up of aerial organs in many young and fully grown erect annuals, particularly those with a long, drawn-out stem. 
Lethal damage particularly concerns those plantlets left lying on prepared ground before sowing, and also those damaged during the harrowing of germinating autumn-sown cereals, in damp periods. Damage involves plant organs harmed by crushing, being torn apart or being sectioned. The organs concerned form part of the plant axis (i.e. stem, hypocotyl, mesocotyl or even the root) or possibly just the leaves (cotyledons and coleoptyl). Both aerial as well as underground parts may be involved and this leads to a single main part being left (in the case of amputation of the cotyledons) or two or more, in the case of fragmentation. No part succeeds in regenerating, possibly for more than one reason: the organogenetic capacity is not yet properly developed (arguably, a problem involving growth substances), insufficient reserves for forming new buds and roots; and severe weakening caused by lack of sap, or due to pathogenic organisms and pests. Such hypotheses largely remain to be tested to enable improvement in mechanical techniques.

\subsubsection{Tolerance}

Mechanical damage from withering, exhaustion of reserves or lethal damage to the plant generally lead to plant death. The period during which plants are most exposed is when they are at the plantlet stage, when shoots begin to appear. The damage is probably lethal for all plant parts, although this remains to be verified. Proof should take into account the stage of development. The species involved is probably important here. The hypocotyl, or other plant part, incurs damage, particularly with respect to underground parts and the depth from which shoots are produced.

With fully grown plants, particularly annuals, cutting the main stem is more difficult than with young plants. Decapitating aerial parts is not necessarily enough to kill the plant.

Those traits describing the plant's sensitivity to lethal damage are useful when discussing tolerance. Sclerification, the size of main axes, the relationship between the size of the plantlet and seed, and the depth from which shoots appear are all worth taking into account. Due to the mechanical vibration that accompanies the use of tine harrows, such implements are probably more effective at inflicting damage. The mechanisms leading to the weed's death following damage are, from an organographic standpoint, probably similar to those following either weeding using thermal techniques or contact weed killers.

Different degrees of control are possible, with lethal damage being the most extreme. At the other end of the scale is the slowing down of development. The differences, as far as wearing the plant down is concerned, might simply be no more than quantitative.

\section{CONCLUSION}

Upon analysing the mechanisms by which growing weed plants are mechanically destroyed, three main processes appear to be involved: direct lethal injury, exhaustion of reserves and withering. Observation points to each process depending on the type of injury inflicted, along with the actual biology of the plant itself and, in the case of withering, the lack of water to which the plant is exposed.

Where plantlets are involved, all three types of injury appear easily attainable. On the other hand, perennial weeds possessing tougher organs involve a more difficult type of destruction to attain:
- Withering (always dependent on the lack of water) is more of a candidate with species with sprouting organs near the surface - though taprooted plants constitute an exception where sub-soilers are used.

- Exhausting the weed plant, a slow but sure process, appears more suitable against plants with deep regenerating organs, but not exclusively so.

In the use of mechanised control methods, the most important aspects of the biology of the weed plant are the depth at which those organs likely to regenerate occur, their possible dormant season and, possibly, their life span. Such an approach is valid where intervention involves the whole plot area, or simply just a part (e.g. between crop rows). But where a succession of interventions is involved, changing the method probably translates into going back to square one.

The optimisation of mechanised methods of control should take into account: the biology of the weed plants involved, the pedoclimate within the soil, crop rotation (choice of crops and length of time between each) and, where applicable (i.e. in the case of plants exhibiting seasonal growth), the time of year. Working out the mechanisms by which weeds die after damage would enable the effect of the weather to be evaluated, and would also influence the choice of implement used. Information relating to the comparative biology of the weed plants involved ought to take into account the above aspects as well as a statistical evaluation of the general principles outlined above, i.e.:

- The number of interventions needed, plus the time between each one and the degree of dehydration to which the weed plant is exposed - all calculated according to the object in view (which may be anything from slowing down the weed's progression to its complete eradication).

- The probability of the damage to the weed plant actually having an effect.

- The difficulty in uprooting, with regard to both the desired end result and the stage of development at the time of intervening.

In evaluating how a particular technique has performed, the time before it is possible to record results and the relevant information to be recorded will depend on the biology of the particular weed involved. The time of year in which growth and propagation occur and the time before new growth is produced after intervention are all important here. When evaluating trials, particularly with perennial weeds propagating vegetatively, it would be better to think first of recording the reduction in plagiotropic growth (as measured against a control) than the number of aerial shoots produced (e.g. per unit surface area).

Acknowledgments: The author wishes to thank the following scientists for their comments: Laurent Beillard (Laboratoire d'Écologie et Sciences Phytosanitaires, École Nationale Supérieure Agronomique de Rennes, France), Hervé Daniel (Institut National d'Horticulture, Angers, France), Jacques Maillet (École Nationale Supérieure Agronomique de Montpellier, France), Daniel Cloutier (Institut de Malherbologie, Sainte-Anne-de-Bellevue, Québec) and Christian Boulet (Université de Nantes, Nantes, France); and G.B. Wakefield for advice concerning preparing the text in English.

\section{REFERENCES.}

Anon. (1968) Weed control. Principles of plant and animal pest control, Vol. 2, National Academy of Sciences, Washington, $471 \mathrm{p}$.

Arny A.C. (1927) Successful eradication of perennial weeds, Rep. Ontario Agric. Exp. Union for 1926, 58-64. 
Arny A.C. (1932) Variations in the organic reserves in underground parts of five perennial weeds from late April to November, Minnesota State Tech. Bull. 84, 1-28.

Barr C.G. (1940) Organic reserves in the roots of bindweed, J. Agr. Res. 60, 391-413.

Bourdot G.W. (1984) Regeneration of yarrow (Achillea millefolium L.) rhizome fragments of different lenghts from various depths in the soil, Weed Res. 24, 421-429.

Boyd J.W., Murray D.S. (1982) Growth and development of Silverleaf Nightshade Solanum eleagnifolium, Weed Sci. 30, 238-243.

Brenchley W.E. (1920) Weeds of farm land. Longman, Green and Co., London, $239 \mathrm{p}$.

Buckman P. (1855) On agricultural weeds, J. Roy. Ag. Soc. England 16, 359-381.

Chancellor R.J. (1968) The value of biological studies in weed control, Proc. 9th Br. Weed Control Conf. 3, 1129-1135.

Chicouene D. (1991) Les mauvaises herbes des champs de grandes cultures : inventaire, biologie, écologie, dynamique des infestations en Bretagne, Thèse, Université de Rennes, $148+64$ p.

Chicouene D. (1992) Profondeur de formation des organes souterrains de propagation végétative et mode d'hivernage des mauvaises herbes pérennes en Bretagne, IX ${ }^{\mathrm{e}}$ Colloque Intern. Bio. Mauvaises Herbes, Association Nationale de Protection des Plantes, pp. 75-84.

Chicouene D. (1996) Typologie des périodes de levée des mauvaises herbes à partir d'organes végétatifs sous climat tempéré océanique, $\mathrm{X}^{\mathrm{e}}$ Colloque Intern. Bio. Mauvaises Herbes, Association Nationale de Protection des Plantes, pp. 7-15.

Chicouene D. (1999) Déchaumage mécanique : prise en compte de la biologie des mauvaises herbes, Phytoma - la défense des végétaux 519, 10-14.

Derscheid L.A., Nash R.L., Wicks G.A. (1961) Thistle control with cultivation, cropping and chemicals, Weeds 9, 90-102.

Drottij S. (1929) Harrowing to control weeds in cereals, Meddel. Centralanst. Forsoksv. Jordbrusomradet 348, 1-23.

Evans S.A. (1962) Weed destruction, a farmers' and students' guide, Blackwell Scientific Publications, Oxford, $172 \mathrm{p}$.

Fail H. (1956) The effects of rotary cultivation on the rhizomatous weeds, J. Agr. Eng. Res., 68-80.

F.A.O. (1958) Méthodes de désherbage, Organisation des Nations Unies pour l'alimentation et l'agriculture, Rome, $208 \mathrm{p}$.

F.A.O. (1988) La lutte raisonnée contre les mauvaises herbes, Organisation des Nations Unies pour l'alimentation et l'agriculture, Rome, $159 \mathrm{p}$.

Fryer J.D., Evans S.A. (1970) Weed control handbook, Vol. 1, principles. 5th ed., Blackwell Scientific Publications, Oxford and Edinburgh, $494 \mathrm{p}$.

Grummer G. (1963) Das Verhalten von Rhizomen der Quecke (Agropyron repens) gegen trockene Luft, Weed Res. 3, 44-51.

Hakansson S. (1967) Experiments with Agropyron repens (L.) Beauv I. Development and growth, and the response to burial and response to burial at different developmental stages, Lantbr. högsk. Annlr. $33,823-873$.

Hakansson S. (1969) Experiments with Sonchus arvensis L. I. Development and growth, and the response to burial and defoliation in different developmental stages, Lantbr. högsk. Annlr. 35, 989-1030.

Hakansson S. (1975) Perennial grass weeds in Europe, Symp. Status, Bio. Cont. Grassweeds Europe 2, 71-83.

Hakansson S. (1982) Multiplication, growth and persistence of perennial weeds - in Biology and ecology of weeds, Dr W. Junk Publishers, The Hague, pp. 123-135.

Hakansson S., Wallgren B. (1975) The control of rhizomatous grass weeds by soil cultivation in late summer and autumn under Swedish conditions, Symp. Status, Bio. Cont. Grassweeds Europe 2, 304313 .
Hitchcock A.S., Clothier G.L. (1898) Vegetative propagation of perennial weeds, Kan. Agr. Exp. Sta. Bul. 76, 1-23.

Hogdson J.M. (1972) The response of of Canada Thistle ecotypes to 2,4 D, Amitrole, and intensive cultivation, Weed Sci. 18, 253-255.

Ilnicki R.D., Fertig S.N. (1962) Life history studies as related to weed control in the northeast. 3- Horse Nettle. Northeast Regional Publication, Agricultural Experiement Station, University of Rhode Island, $54 \mathrm{p}$.

Irmisch T. (1857) Ueber die Keimung und die Erneuerungsweise von Convolvulus sepium und C. arvensis, so wie über hypokotylische Adventivknospen bei krautartigen phanerogamen Pflanzen, Bot. Zeit. 15, 433-443, 449-462, 489-497.

Jones P.A., Blair A.M., Orson J.H. (1995) The effect of different types of physical damage to four weeds species, Brighton Crop Protection Conference - Weeds, pp. 653-658.

Jones P.A., Blair A.M., Orson J.H. (1996) Mechanical damage to kill weeds. Second International Weed Control Congress, Copenhagen, pp. $949-954$.

King L.J. (1966) Weeds of the world, biology and control, Hill, London, $526 \mathrm{p}$.

Klingman G.C. (1961) Weed control as a science, Wiley, New York, London, $421 \mathrm{p}$.

Korsmo E. (1930) Unkrauter im Ackerbau der Neuzeit. Biologische und practische Untersuchungen. J. Springer, Berlin, 580 p.

Leakey R.R.B. (1981) Adaptative biology of vegetatively regenerating weeds, Adv. Appl. Biol. 6, 57-90.

Magnusson M.U., Wyse D.L., Spitzmueller J.M. (1987) Canada Thistle (Cirsium arvense) propagation from stem sections, Weed Sci. 35, 637-639.

Mann H., Cavers P.B. (1979) The regenerative capacity of root cuttings of Taraxacum officinale under natural conditions, Can. J. Bot. 57, 1783-1791.

Muencher W.C. (1955) Weeds, Macmillan Company, New York, 2nd ed., $560 \mathrm{p}$.

Muzic T.J. (1970) Weed biology and control, McGraw-Hill book company, New York, $273 \mathrm{p}$.

Palis E. (1996) Les travaux mécaniques du sol post-moisson et la dynamique des rhizomes d'Elymus repens (L.) Gould dans la culture des pommes de terre, $\mathrm{X}^{\mathrm{e}}$ colloque International sur la Biologie des mauvaises herbes, Dijon, pp. 373-378.

Pavlychenko T.K., Kirk L.E., Kossar W. (1940) Eradication of perennial weeds by the shallow cultivation method, Bulletin University of Saskatchewan, College of Agriculture 100, 3-8.

Prentiss A.N. (1889) On root propagation of Canada Thistle, Cornell Agr. Expt. Sta. Bul. 15, 190-191.

Rasmussen J. (1992) Testing harrows for mechanical control of annual weeds in agricultural crops, Weed Res. 32, 267-274.

Rasmussen J. (1996) Mechanical weed management, Second International Weed Control Congress, Copenhagen, pp. 943-948.

Robbins W.W., Crafts A.S., Raynor R.N. (1942) Weed control, a textbook and manual, McGraw-Hill book Company, New York, London, $542 \mathrm{p}$.

Salisbury S.E. (1962) The biology of garden weeds, Vincent Square, London, $50 \mathrm{p}$.

Seely C.I. (1952) Controlling perennial weeds with tillage, Idaho Agr. Exp. Stat. Bull. 288

Timmons F.L. (1941) Results of bindweed control experiments at the Fort Hays Branch Station, Kansas Agr. Expt. Sta. Bull. 296, 1-50.

Welton F.A., Morris V.H., Hartzler A.J. (1929) Organic food reserves in relation to the eradication of Canada Thistle, Ohio Agr. Expt. Sta. Bull. 441, 1-25.

Zimdahl R.L. (1993) Fundamentals of weed science, Academic Press, San Diego, $450 \mathrm{p}$. 